\title{
Kemampuan Berpikir Kreatif Matematis Menggunakan Model Pembelajaran Cooperative Script Berbantuan Aplikasi Geogebra di SMA Negeri 1 Rantau Utara
}

\author{
Monica Clara Purba ${ }^{1}$, Nurlina Ariani Harahap ${ }^{2}$ \\ ${ }^{1,2}$ Program Studi Pendidikan Matematika, Fakultas Ilmu Pendidikan, Universitas Labuhanbatu, \\ Jl. Sisingamangaraja Labuhanbatu Sumatera Utara (21415) Indonesia \\ monicaclarapurba@gmail.com
}

\begin{abstract}
The purpose of this study was to see the ability to think creatively mathematically using the Cooperative Script learning model assisted by the Geogebra application. The method used in this research is the experimental method. The design of this study was a pretest-posttest control group design involving two groups. The researcher uses a quantitative research method using the Coperative Script learning method, the population of this study is class XI science students at SMA Negeri 1 Rantau Utara in the 2020/2021 academic year. The technique used is random according to class, choosing 2 classes, namely the experimental class and the control class. Class XI IPA ${ }^{2}$ is an experimental class with 36 students and class XI IPA ${ }^{1}$ in a control class is 36 students. It is known that the large influence of the Cooperative Script learning model with the Geogebra application on students' mathematical creative thinking skills is $34.17 \%$, while the conventional learning method only has an effect of $12.92 \% .21 .25 \%$.
\end{abstract}

Keywords: Learning Process, Mathematics, Cooperative Script, Geogebra application, CAR

\begin{abstract}
Abstrak
Tujuan penelitian ini untuk melihat kemampuan berfikir kreatif matematis menggunakan model pembelajaran Cooperative Script berbantuan aplikasi Geogebra. Metode digunakan penelitian ini adalah metode eksperimen. Disain penelitian ini merupakan desain kelompok control pretes-protes (pretest- posttest control grup design) melibatkan dua kelompok. Peneliti menggunakan metode penelitian kuantitatif menggunakan metode pembelajaran Coperative Script, populasi penelitian ini adalah siswa kelas XI IPA SMA Negeri 1 Rantau Utara tahun ajaran 2020/2021. Teknik digunakan adalah acak menurut kelas, memilih 2 kelas, yaitu kelas eksperimen dan kelas kontrol. Kelas XI IPA ${ }^{2}$ merupakan kelas eksperimen berjumlah 36 siswa dan kelas XI IPA ${ }^{1}$ kelas kontrol berjumlah 36 siswa. Diketahui bahwa besar pengaruh model pembelajaran Cooperative Script dengan aplikasi Geogebra terhadap kemampuan berfikir kreatif matematis siswa adalah sebesar $34.17 \%$, sedangkan metode belajar konvensional hanya berpengaruh sebesar $12.92 \%$ disimpulkan ada perbedaan hasil belajar siswa terhadap model pembelajaran Cooperative Script dengan aplikasi Geogebra dan konvensional dengan perbedaan sebesar 21.25\%.
\end{abstract}

Kata kunci: Proses Belajar, Matematika, Cooperative Script, aplikasi Geogebra, PTK

Copyright (c) 2021 Monica Clara Purba, Nurlina Ariani Harahap

$\triangle$ Corresponding author: Monica Clara Purba

Email Address: monicaclarapurba@gmail.com (Jl. Sisingamangaraja Labuhanbatu Sumatera Utara (21415) Indonesia)

Received 01 June 2021, Accepted 29 June 2021, Published 26 July 2021

\section{PENDAHULUAN}

Pendidikan merupakan proses yang bisa mengubah objek yang ada pada dirinya. Pendidikan yang bersifat dinamis, melalui pendidikan mampu mempertahankan bahkan mengembangkan nilai-nilai yang dikehendaki sesuai dengan usaha-usaha pengembangan manusia yang seutuhnya. Menurut (Eviliasani et al., 2018) Matematika adalah ilmu pasti yang hakikatnya menjadi dasar dari ilmu lain, sehingga matematika itu saling berhubungan pada ilmu lainnya. Matematika merupakan kunci ke arah peluang-peluang, jadi untuk seorang peserta didik yang berhasil mempelajarinya maka akan membuka pintu karir yang cemerlang. Upaya meningkatan kualitas pendidikan merupakan salah satu fokus di dalam pembangunan pendidikan 
Indonesia dewasa ini. Salah satu pendekatan pemecahan berbagai permasalahan yang digunakan dalam rangka peningkatan kualitas pendidikan itu adalah pemanfaatan penelitian pendidikan. Sama seperti dalam peningkatan kualitas pendidikan matematika terutama dalam pengajarannya. Dari hal tersebut diperlukan peingkatan pembelajaran matematika di SMA yang tertuju pada kurikulum. Pendapat (Warni \& Ariani Hrp, 2019) Dampak untuk selanjutnya yaitu banyak peserta didik sanggup menyajikan tingkat hapalan yang baik pada suatu materi ajar yang diterimanya, tetapi pada kenyataannnya mereka tidak mengerti bagaimana pengetahuan tersebut akan bermanfaat dalam kehidupannya.

Pembelajaran matematika merupakan bagian dari pendidikan menempati kedudukan yang sangat penting dalam peningkatan sumber daya manusia. Hal ini sejalan dengan tujuan yang diinginkan terhadap pembelajaran matematika. Melalui belajar matematika, kemampuan berpikir kritis, sistematis, dan kreatif dapat dikembangkan. Pembelajaran matematika merupakan suatu proses dimana siswa diberikan pengalaman belajar melalui kegiatan-kegiatan yang telah disusun dengan tujuan siswa mampu menguasai konsep atau materi matematika yang dipelajari (Kurniason \& Yani, 2021). Pada pembelajaran matematika guru sebagai gudang ilmu yang menkonstruksi pembelajaran sehingga pengajarannya berpusat ke guru. Siswa sebagai pendengar, duduk dengan tenang sembari mendengarkan penjelasan guru, kemudian menirukan cara guru menyelesaikan soal yang telah dikerjakan di depan kelas. Sedangkan guru memberi pelajaran matematika, membuktikan rumus, dan memberikan contoh soal. Hal ini dapat membuat siswa kesulitan dalam memecahkan masalah dalam pembelajaran matematika (Studi \& Matematika, 2019).

Salah satu kemampuan berpikir tingkat tinggi yang kini sudah menjadi pusat perhatian guru dalam pembelajaran matematika merupakan pengertian dari kemampuan berpikir kreatif. Akan tetapi dilapangan masih menunjukkan kurangnya optimal perkembangan dari kemampuan berpikir kreatif siswa. Ketika guru mampu memberi kepercayaan kepada siswa baik dalam mengemukakan pendapat atau memberikan kesempatan kepada siswa untuk mengerjakan tugas sesuai dengan kebutuhannya. Pendapat (Minarti \& Senjayawati, 2015) Kita bisa melihat bahwa terdapat hubungan antara kepercayaan diri dengan kemampuan matematis siswa. Hal ini, dapat memberikan efek positif dalam mengembangkan kemampuan berpikir kreatif siswa. Untuk memunculkan sikap kreatif siswa, dibutuhkan suatu model pembelajaran yang sesuai dan betul-betul memberikan kontribusi yang baik dalam peningkatannya. Dalam menggunakan model pembelajaran yang baik dan menarik dalam proses belajar membantu siswa lebih tenang dalam menerima materi pelajaran. Ketidak sesuaian model pembelajaran yang diterapkan terkadang menimbulkan kebosanan siswa, dan siswa kurang memahami materi. Maka seorang guru seharusnya jelih dalam memilih dan memilah model pembelajaran untuk kemampuan berpikir kreatif siswa. Kemampuan berpikir kreatif sangat dibutuhkan oleh siswa mengingat bahwa dewasa ini ilmu pengetahuan, teknologi berkembang sangat pesat dan memungkinkan siapa saja bisa memperoleh informasi secara cepat dan mudah dari berbagai sumber dan tempat manapun di dunia. Kemampuan berpikir kreatif dapat dikembangkan melalui aktivitas-aktivitas kreatif pada pembelajaran matematika. Kemampuan berpikir kreatif bisa dikembangkan melalui aktivitasaktivitas kreatif dalam pembelajaran matematika. Salah satu penyebab kurangnya minat siswa terhadap matematika adalah pada pembelajaran matematika yang sarat dengan konsep matematika yang abstrak dan 
tanpa dikaitkan dengan kehidupan sehari-hari. Kompetensi yang diharapkan dimiliki oleh siswa setelah mempelajari matematika adalah minat terhadap matematika, rasa tertarik atau minat siswa terhadap matematika menjadi salah satu faktor penting untuk menentukan keberhasilan pembelajaran matematika (Eviliasani et al., 2018).

Pada pemecahan masalah matematika dibutuhkan pemikiran yang kreatif dan berhubungan dalam kemampuan untuk memberikan lebih dari satu ide dengan cara yang menarik supaya beragam serta memberikan penjelasan secara rinci dari penyelesaian masalah matematika (Sumartini, 2019). Sejalan dengan pendapat (Faturohman \& Afriansyah, 2020) Kemampuan berpikir kreatif adalah kemampuan yang tergolong sebagai kemampuan berpikir tingkat tinggi atau High Order Thinking (HOT). Begitu juga menurut (Pratiwi et al., 2019) Manusia diwajibkan supaya menjadi manusia yang kreatif. Tidak bisa dipungkiri dengan adanya perkembangan dunia yang semakin maju, maka perkembangannya menutut manusia menjadi pribadi yang kreatif. Pendapat (Sanusi et al., 2020) Permasalahan kemampuan berpikir kreatif siswa di sekolah yang masih rendah disebabkan oleh pemberian tugas dan cara mengajar guru yang belum variatif. Menurut (Maksum \& Rahayu, 2013) Akan diuraikan bersama. Peran guru sebagai fasilitator yang mengarahkan peserta didik untuk mencapai tujuan belajar. Model pembelajaran Cooperative Script telah mengalami berbagai adaptasi, sehingga menimbulkan beberapa pengertian dan bentuk yang sedikit berbeda antara yang satu dengan lainnya, pada intinya sama. Pada model pembelajaran Cooperative Script siswa akan dihubungkan dengan temannya dan akan berperan sebagai pembicara dan pendengar (Yudiawati \& G. P, 2017).

Berdasarkan hasil observasi dan wawancara dengan guru matematika SMA Negeri 1 Rantau Utara kelas XI, jelas bahwa beberapa faktor yang mempengaruhi proses pembelajaran salah satunya kurang tepatnya guru dalam memilih model pembelajaran yang sesuai dengan materi ajar. Perlu diperhatikan, tidak semua materi ajar guru yang harus menerangkan di depan kelas, tetapi bagaimana melibatkan siswa dalam proses belajar tersebut. Pelaksanaan pembelajaran matematika melalui penerapan model pembelajaran kooperatif tipe cooperative script untuk meningkatkan hasil belajar peserta didik. Adapun tujuan penelitian tindakan kelas ini adalah untuk mengetahui cara penerapan model pembelajaran kooperatif tipe cooperative script untuk meningkatkan hasil belajar matematika peserta didik (Sari et al., 2019). Pada penelitian ini menggunakan model pembelajaran Cooperative Script untuk menciptakan proses pembelajaran yang lebih berpusat untuk peserta didik dan memotivasi siswa demi meningkatnya hasil belajar matematika siswa (Suryani, 2012).

Dalam meningkatkan kemampuan berpikir kreatif siswa, perlu dikaji juga penguasan siswa terhadap komputer. Pada penelitian ini akan menjelaskan tentang kemampuan berpikir kreatif siswa dengan menggunakan aplikasi matematika sebagai media pembelajaran, yaitu salah aplikasinya adalah geogebra. Geogebra merupakan salah satu software atau aplikasi yang dapat digunakan sebagai media pada pembelajaran matematika. Aplikasi tersebut dikembangkan oleh Markus Hohenwarter pada tahun 2001. Menurutnya, geogerbra adalah program komputer gratis yang dirancang untuk menggabungkan geometri, kalkulus, alabar dalam satu lingkunan yang dinamis. Program bisa diunduh di http://www.geogebra.org. 
Dari beberapa penelitian menunjukkan bahwa geogebra mampu mendorong proses eksperimen siswa. Dengan pemanfaatan media tersebut siswa mendapatkan pengalaman, dan siswa mandiri mengkonstruk konsep secara umum (Eviliasani et al., 2018).

Perkembangan komputer yang pesat sangat berdampak baik pada pembelajaran matematika. Geogebra merupakan salah satu aplikasi komputer gratis yang dapat dimanfaatkan sebagai media pembelajaran terkhusus pada materi Program Linear. Dalam menjelaskan tentang konsep daerah dan menyelesaikan masalah pemrograman linear membutuhkan media bantu yaitu dengan menggunakan geogebra. Berdasarkan analisis di atas, peneliti akan melakukan penelitian dengan judul sebagai berikut: "Meningkatkan Kemampuan Berpikir Kreatif Matematis Siswa SMA Melalui Pembelajaran Inkuiri Berbantuan Software Geogebra Pada Pokok Bahasan Program Linear”.

\section{METODE}

Metode yang digunakan pada penelitian ini adalah metode eksperimen. "Penelitian eksperimen merupakan penelitian yang benar - benar untuk melihat sebab-akibat. Disain penelitian ini merupakan desain kelompok control pretes-protes (pretest- posttest control grup design) yang melibatkan dua kelompok. Dalam penelitian ini menggunakan metode penelitian kuantitatif yang menggunakan metode pembelajaran Coperative Script dilakukan untuk pengambilan data dalam pencapaian adanya peningkatan berpikir kreatif matematis di SMA Negeri 1 Rantau Utara. Pengambilan populasi pada penelitian ini adalah siswa kelas XI IPA SMA Negeri 1 Rantau Utara tahun ajaran 2020/2021. Teknik yang digunakan adalah acak menurut kelas, dengan memilih 2 kelas, yaitu kelas eksperimen dan kelas control. Dimana kelas XI IPA ${ }^{2}$ merupakan kelas eksperimen yang berjumlah 36 siswa dan kelas XI IPA ${ }^{1}$ sebagai kelas kontrol yang berjumlah 36 siswa.

Instrumen tes yang digunakan pada penelitian ini merupakan tipe soal uraian. Hal tesebut digunakan karena soal uraian mampu memperlihatkan sifat kreatif siswa dalam menyelesaikan soal - soal bervariasi. Beberapa soal dapat dijawab dengan mudah menggunakan aplikasi geogebra. Pada uji peningkatan kemampuan berpikir kreatif matematis terhadap siswa untuk melihat perbedaan peningkatan kemampuan berpikir kreatif matematis siswa antara yang menggunakan model pembelajaran Cooperative Script dengan yang menggunakan model pembelajaran konvesional. Setelah data hasil pretes dan postes dianalisis, besarnya mutu peningkatan kemampuan berpikir kreatif matematis siswa dihitung menggunakan rumus gain ternormalisasi.

\section{HASIL DAN DISKUSI}

Berikut ini merupakan sajian statistic deskriptif skor pretes dan Gain untuk kemampuan berpikir kreatif matematis. Data hasil belajar Matematika peserta didik pada kelas eksperimen dan kontrol diambil dari hasil penelitian terhadap soal yang diberikan kepada sampel sebanyak 10 soal uraian.

\section{Analisis DataTes}

Untuk menganalisis data dilakukan Pre-Test dan Post-Test terhadap kelas eksperimen dan kelas 
control. Pre-Test dan Post-Test yang diberikan kepada siswa berupa tes essay yang berfungsi untuk melihat kemampuan berpikir kreatif matematis siswa dan pemahamn konsep siswa dengan materi uji yang disesuaikan dengan tingkatan pendidikan siswa. Pengolahan data hasil Pre-Test dan Post-Test dilakukan dengan menggunakan MS Excel dan SPSS. Pre-Test diberikan kepada siswa sebelum penerapan model pembelajaran cooperative script berbantuan aplikasi geogebra dan Post-Test diberikan kepada siswa setelah penerapan model pembelajaran cooperative script berbantuan aplikasi geogebra. Hasil Pre-Test dan Post-Test yang diperoleh adalah sebagai berikut:

\section{AnalisisDeskriptif}

Analisis ini bertujuan untuk memaparkan dan menggambarkan data penelitian berupa jumlah data, nilai minimal, nilai maksimal, nilai rata-rata. Berikut adalah hasil statistik deskriptif:

Tabel 1. Descriptive Statistics

\begin{tabular}{lrrrrr}
\hline & N & Minimum & Maximum & Mean & Std. Deviation \\
\hline Pre-Test Eksperimen & 36 & 30 & 65 & 51.94 & 11.544 \\
\hline Post-Test Eksperimen & 36 & 70 & 100 & 86.11 & 10.427 \\
\hline Pre-Test Kontrol & 36 & 45 & 70 & 64.31 & 6.777 \\
\hline Post-Test Kontrol & 36 & 65 & 85 & 77.22 & 7.411 \\
\hline Valid N (listwise) & 36 & & & & \\
\hline
\end{tabular}

Berikut adalah bagan untuk hasil tes siswa:

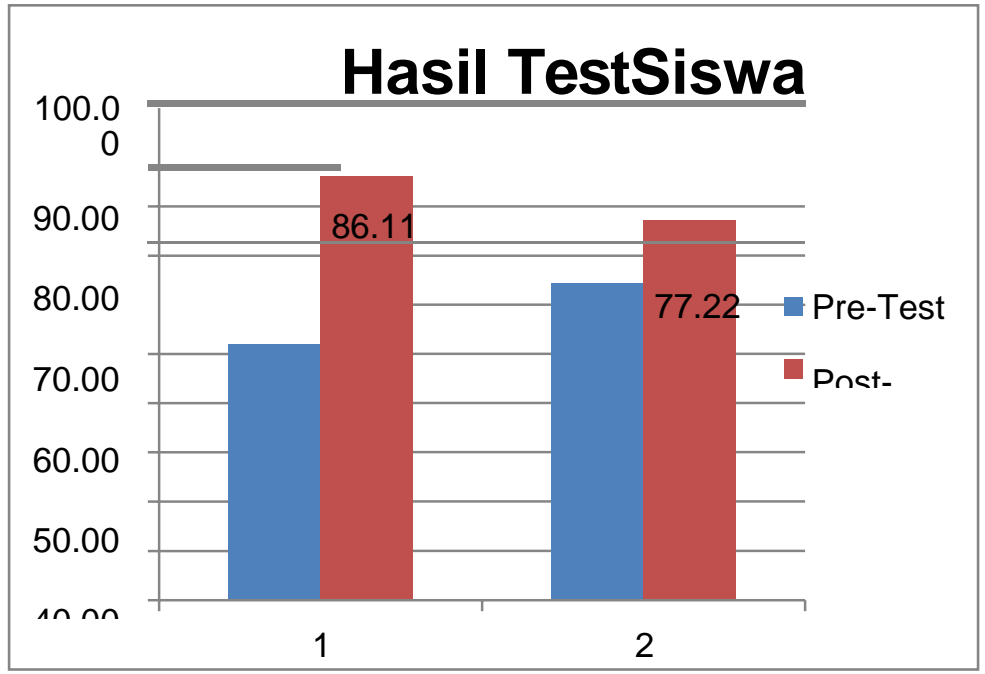

Gambar 1. Bagan Descriptive Statistics

Berdasarkan tabel dan gambar diatas diketahui nilai pre-test siswa untuk kelas eksperimen sebesar 59.94 dan kelas kontrol sebesar 64.31 serta nilai post-test untuk kelas eksperimen sebesar 86.11 dan kelas kontrol sebesar72.22.

\section{Uji Normalitas}

Pengujian uji normalitas data dilakukan untuk mengetahui apakah data berdistribusi normal yang merupakan syarat mutlak untuk pengujian analisis parametrik (paired sample t test dan independent sample t test) apabila data tidak normal maka akan dilakukan uji Wilcoxon dan uji Mann Whitney. Berikut 
hasi uji normalitas data:

Tabel 2. Tests of Normality

\begin{tabular}{llllllll}
\hline & & \multicolumn{3}{c}{ Kolmogorov-Smirnov ${ }^{\mathrm{a}}$} & \multicolumn{3}{c}{ Shapiro-Wilk } \\
\cline { 2 - 8 } Hasil Belajar Siswa & Kelatistic & df & Sig. & Statistic & df & Sig. \\
\cline { 2 - 8 } & Pre-Test Eksperimen & .266 & 36 & .000 & .795 & 36 & .000 \\
\cline { 2 - 8 } & Post-Test Eksperimen & .180 & 36 & .005 & .876 & 36 & .001 \\
\cline { 2 - 8 } & Pre-Test Kontrol & .272 & 36 & .000 & .809 & 36 & .000 \\
\cline { 2 - 8 } & Post-Test Kontrol & .297 & 36 & .000 & .777 & 36 & .000 \\
\hline
\end{tabular}

a. Lilliefors Significance Correction

Berdasarkan hasil uji nomalitas dapat diketahui bahwa data berdistriusi tidak normal dilihat dari nilai Sig < 0.05. Dengan demikian maka tidak dapat dilakukan uji paired sample t test terhadap data, melainkan uji Wilcoxon dan uji Mann Whitney.

\section{Uji Wilcoxon}

Pengujian ini bertujuan untuk melihat adanya perbedaan sebelum dan setelah penerapan model pembelajaran cooperative script berbantuan aplikasi geogebra dalam peningkatan kemampuan berpikir kreatif matematis siswa. Berikut hasil analisis data:

Tabel 3. Wilcoxon Test Statistics

\begin{tabular}{lrr}
\hline & $\begin{array}{r}\text { Post-Test Eksperimen - } \\
\text { Pre-Test Eksperimen }\end{array}$ & $\begin{array}{r}\text { Post-Test Kontrol - } \\
\text { Pre-Test Kontrol }\end{array}$ \\
\hline $\mathrm{Z}$ & $-5.269^{\mathrm{b}}$ & $-5.433^{\mathrm{b}}$ \\
\hline Asymp. Sig. (2-tailed) & .000 & .000 \\
\hline
\end{tabular}

a. Wilcoxon Signed Ranks Test

b. Based on negative ranks.

Dari hasil analisis tersebut diketahui adanya perbedaan setelah penerapan model pembelajaran cooperative script berbantuan aplikasi geogebra dalam peningkatan kemampuan berpikir kreatif matematis siswa dilihat dari nilai Sig. (2-tailed) $0.000<0.05$.

\section{Uji MannWhitney}

Pengujian ini bertujuan untuk melihat adanya pengaruh penerapan model pembelajaran cooperative script berbantuan aplikasi geogebra dalam peningkatan kemampuan berpikir kreatif matematis siswa. Berikut hasil analisis data:

Tabel 4. Mann Whitney Test Statistics

\begin{tabular}{lr} 
& Hasil BelajarSiswa \\
\hline Mann-Whitney U & .000 \\
\hline Wilcoxon W & 666.000 \\
\hline Z & -7.360 \\
\hline Asymp. Sig. (2-tailed) & .000 \\
\hline a. Grouping Variable: Kelas
\end{tabular}

a. Grouping Variable: Kelas 
Dari hasil analisis tersebut diketahui adanya pengaruh penerapan model pembelajaran cooperative script berbantuan aplikasi geogebra dalam peningkatan kemampuan berpikir kreatif matematis siswa dilihat dari nilai Asymp. Sig. (2-tailed) $0.000<0.05$.

\section{KESIMPULAN}

Berdasarkan hasil penelitian dan pengolahan data yang telah dibahas dapat disimpulkan bahawa penerapan model pembelajaran cooperative script berbantuan aplikasi geogebra memiliki dampak terhadap peningkatan kemampuan berpikir kreatif matematis siswa ditinjau dari hasil belajar siswa. Selain itu diketahui bahwa besar pengaruh penerapan model pembelajaran cooperative script berbantuan aplikasi geogebra dalam peningkatan kemampuan berpikir kreatif matematis siswa sebesar $34.17 \%$ sedangkan metode belajar konvensional hanya berpengaruh sebesar $12.92 \%$ serta dapat disimpulkan ada perbedaan hasil belajar siswa terhadap model pembelajaran Cooperative Script dengan aplikasi Geogebra dan konvensional dengan perbedaan sebesar $21.25 \%$, sehingga dapat disimpulkan adanya pengaruh dan perbedaan hasil belajar siswa setelah penerapan model pembelajaran cooperative script berbantuan aplikasi geogebra dalam peningkatan kemampuan berpikir kreatif matematis siswa. Sehingga penerapan model pembelajaran cooperative script berbantuan aplikasi geogebra dalam peningkatan kemampuan berpikir kreatif matematis siswa serta meningkatkan nilai belajar siswa khususnya dalam mata pelajaranmatematika.

\section{UCAPAN TERIMA KASIH}

Puji dan Syukur saya panjatkan kehadirat Tuhan Yang Maha Esa telah memberikan petunjukNya sehingga saya dapat menyelesaikannya. Terimakasih saya ucapkan kepada Bapak Drs. Jaliluddin, M.Pd. selaku Kepala Sekolah SMAN 1 Rantau Utara yang telah bersedia memberikan izin, dan membantu saya untuk menyelesaikan penelitian ini. Terimakasih kepada Bapak/Ibu guru Matematika serta Wali kelas yang telah membantu saya untuk mempermudah dalam proses penelitian pengambilan data. Terikasih saya ucapkan kepada siswa - siswi kelas XI IPA ${ }^{1}$ dan XI IPA ${ }^{2}$ SMAN 1 Rantau Utara atas kerjasamanya dalam pengambilan data. Terimakasih kepada Ibu Nurlina Ariani Harahap, S.Pd., M.Pd., yang telah membimbing selama ini sehingga dapat menyelesaikan publikasi ini. Terimakasih kepada Orang Tua saya, Teman Teman dan Saudara/i yang sudah memberikan dukungan, semangat serta doanya sehingga saya dapat menyelesaikan publikasi ini.

\section{REFERENSI}

Eviliasani, K., Hendriana, H., \& Senjayawati, E. (2018). Analisis Kemampuan Berpikir Kreatif Matematis Ditinjau Dari Kepercayaan Diri Siswa Smp Kelas Viii Di Kota Cimahi Pada Materi Bangun Datar Segi Empat. JPMI (Jurnal Pembelajaran Matematika Inovatif), 1(3), 333. https://doi.org/10.22460/jpmi.v1i3.p333-346

Faturohman, I., \& Afriansyah, A. E. (2020). Peningkatan Kemampuan Berpikir Kreatif Matematis Siswa 
melalui Creative Problem Solving. Mosharafa: Jurnal Pendidikan Matematika, 9(1), 107-118. http://journal.institutpendidikan.ac.id/index.php/mosharafa

Kurniason, H. T., \& Yani, A. (2021). Pengaruh Model Pembelajaran Matematika Berbasis Pengajuan dan Pemecahan Masalah terhadap Kemampuan Berpikir Kreatif. Jurnal Pendidikan Dan Pembelajaran ..., 9(2), 99-113. https://jurnal.untan.ac.id/index.php/jpdpb/article/view/17198

Maksum, A., \& Rahayu, M. (2013). MODEL COOPERATIVE SCRIPT BERPENDEKATAN SCIENCE, ENVIRONMENT, TECHNOLOGY, AND SOCIETY (SETS) TERHADAP HASIL BELAJAR Amir Maksum* dan Sri Mantini Rahayu Sedyawati. Inovasi Pendidikan Kimia, 7(1), 1072-1082.

Minarti, E. D., \& Senjayawati, E. (2015). Studi Komperatif Penerapan Pendekatan Kontekstual Dan Pendekatan Kontekstual Bersetting Pembelajaran Cooperative Script Terhadap Kemampuan Representasi Matematis Dan Self Confidence Siswa Smk Di Kota Cimahi. P2M STKIP Siliwangi, 2(2), 169. https://doi.org/10.22460/p2m.v2i2p169-181.176

Pratiwi, L. ajeng, Dwijanto, \& Wijayanti, K. (2019). Analisis Kemampuan Berpikir Kreatif Matematis pada Pembelajaran Read, Think, Talk, Write Ditinjau dari Kecemasan Matematika. Prisma, Prosicing Seminar Nasional Matematika, 2, 576-582.

Sanusi, A. M., Septian, A., \& Inayah, S. (2020). Kemampuan Berpikir Kreatif Matematis dengan Menggunakan Education Game Berbantuan Android pada Barisan dan Deret. Mosharafa: Jurnal Pendidikan Matematika, 9(3), 511-520.

Sari, Y. P., Rusdi, R., \& Muchlis, E. E. (2019). Upaya Meningkatkan Hasil Belajar Siswa Dengan Penerapan Model Pembelajaran Cooperative Script Pada Materi Lingkaran. Jurnal Penelitian Pembelajaran Matematika Sekolah (JP2MS), 2(1), 8-13. https://doi.org/10.33369/jp2ms.2.1.8-13

Studi, P., \& Matematika, P. (2019). Jurnal Pendidikan Matematika RAFA e - ISSN : 2460 - 8726. 111-119. Sumartini, T. S. (2019). Kemampuan Berpikir Kreatif Mahasiswa melalui Pembelajaran Mood, Understanding, Recall, Detect, Elaborate, and Review Mosharafa : Jurnal Pendidikan Matematika Mosharafa : Jurnal Pendidikan Matematika. Mosharafa: Jurnal Pendidikan Matematika, 8(1), 13-24.

SURYANI, R. (2012). Penerapan Model Pembelajaran Cooperative Script Untuk Meningkatkan Hasil Belajar Matematika Siswa Kelas X Sma Taruna Mandiri Pekanbaru. 1-86. Jurnal Pembelajaran Dan Matematika Sigma (JPMS).

Warni, W., \& Ariani Hrp, N. (2019). Peningkatan Kemampuan Penalaran Induktif Matematik Siswa Materi Logika Matematika dengan Menerapkan Model Pembelajaran Contextual Teaching and Learning Kelas X-2 SMA N 1 Torgamba. Jurnal Pembelajaran Dan Matematika Sigma (Jpms), 5(2), 36-42. https://doi.org/10.36987/jpms.v5i2.1412

Yudiawati, N., \& G. P, B. Y. (2017). Penerapan Model Pembelajaran Cooperative Script Untuk Meningkatkan Kemampuan Berpikir Kreatif Matematis Sekolah Menengah Pertama (Smp). TEOREMA : Teori Dan Riset Matematika, 2(1), 63. https://doi.org/10.25157/teorema.v2i1.766 